\title{
PATENT RIGHTS PROTECTION SYSTEM AND FOREIGN DIRECT INVESTMENT (FDI) IN DEVELOPING COUNTRIES
}

\author{
Manda Pratomo \\ Postgraduate Program in Economics, \\ Faculty of Economics and Business, University of Indonesia \\ Depok, Indonesia \\ manda.pratomo@gmail.com
}

\author{
Fithra Faisal Hastiadi \\ Department of Economics, \\ Faculty of Economics and Business, University of Indonesia \\ fithra_faisal@yahoo.com
}

\begin{abstract}
This research is aimed to analyze the effects of the Patent Right Protection (PRP) System in 19 developing countries on the FDI inflow of innovative countries as the home countries (United States, Japan and Germany) in the period where the enforcement of TRIPS Agreement has been put into effect for developing countries. Different from the previous researches in which the measurement of the PRP system only observes the attendance component of the regulations, this research uses an index that captures the effectiveness of implementing the PRP system in a country. The Estimation outcomes indicate that a strong and effective PRP system in a host country can increase the value of FDI inflows into developing countries.
\end{abstract}

Keywords: FDI, Patent Rights Protection (PRP) System, TRIPS Agreement, Developing Countries. JEL Classification : O34; F23

\section{INTRODUCTION}

One of the strategies to accelerate economic growth is through the Foreign Direct Investment (FDI) in industry sector, where the presence of FDI is expected to be followed by knowledge spillover, technology transfer, production efficiency, managerial capability, capital supply and competition effects resulting from multinational firms to domestic firms. All these factors will encourage the increased efficiency and quality in the production process which in parallel can create many jobs and enhance the national economy rate; this is considered that FDI is the main factor in increasing the economic growth (Dunning \& Lundan, 2008; OECD, 2002)

According to UNCTAD (2015), FDI inflows globally decreased by $16 \%$ due to the non-conducive macro world economy, policy uncertainties for investors and geopolitical risks, but the decline was not followed by FDI flows to developing countries that increased by $2 \%$ and reached the highest value of $\$ 681$ billion, whereas China became the largest recipient of the FDI. The increased FDI was due to global economic integration that started since agreements of Uruguay Round in 1994.

World Bank (2002) declared that one of the agreements that changed the paradigm of views of most countries in the globalization policy is the Agreement on Trade-Related Intellectual Property Rights (TRIPS) and cannot be separated from one of the instruments of globalization that is investment.
The IP system ensures that investors' assets can be protected from imitation actions so that this will increase the level of investor confidence.

The relationship between the Patent Rights Protection (PRP) system and FDI inflow will implicate investment policies in the industrial sector because it is related to the decision strategy of the Multinational Company (MNC) location. If the PRP system positively affects FDI inflows such as literature in general, then the government as policy maker can design an industrial investment policy system by considering the effects, in addition to the local improved innovation through technology transfer. However, if PRP does not affect the MNC location decision, then the TRIP agreement is not effective, in particular for countries with low innovations (Ushijima, 2013).

Several studies have analyzed the impacts of the PRP system on the FDI in a number of countries and most literature indicate that a strong PRP system will increase the possibility of the MNC investing in the country; because the PRP system protects the threat of imitation by domestic firms (Glass, 2005; Glass \& Saggi, 2002; Helpman, 1993; Hsu \& Tiao, 2015; Javorcik, 2004; Lee \& Mansfield, 1996; Lesser, 2001; Nabokin, 2014; Nunnenkamp \& Spatz, 2004; Seyoum, 1996, 2006; Ushijima, 2013; Wagh, 2003). However, some studies debate the hypothesis and explain that when the PRP level is strong, then the MNC tends to select licensing rather than FDI, which is in line with the internalization theory with the principle to minimize transaction costs incurred, related to the FDI activity and licensing (Horstmann \& Markusen, 1987; Nicholson, 2007; Smith, 2001; Yang \& Maskus, 2001). Different views on the importance of the PRP system in a country, in particular in developing countries as one of the instruments in attracting FDI, make the issue interesting to be further researched.

The lack of studies that analyzed the relation between the PRP system and FDI flow of the enactment period of the TRIPS agreement for developing countries is caused by the limited measurement of the PRP system across countries. Most of the studies that analyzed the effects of the patent protection level on cross country international economic activities such as trade, economic growth and innovation are Alexiou, et al., 2016; Awokuse \& Yin, 2010a; Ivus, 2010; Papageorgiadis \& Sharma, 2016; Smith, 1999) that used the index established by Ginarte \& Park (1997); Park (2008), whereas the index only accommodated the periodical observation time of five years until 2005. Another weakness of this index is the level of 
patent protection of a country that is only observed based on the existence of a regulation "law on the book", so that the effectiveness of the "law in action" PRP system is not considered. Based thereon, this research will use the index developed by Papageorgiadis, et al. (2014), because it accommodates the observation time period after the TRIPS Agreement is enacted and observes the effectiveness of the PRP system of a country.

This research aims to analyze the effects of the PRP system in developing countries on FDI inflows from the innovator country as the home country in the period following the enforcement of the TRIPS Agreement. Innovative countries that are selected as FDI sources in this research are focused on 3 (three) developed countries: Germany, Japan and the United States. These three countries belong to the top 10 countries with the highest average FDI outward value in the period of 2001-2014 (UNCTAD, 2015). In addition, those countries are also the top patent application abroad during the period as presented in Figure 1 (WIPO, 2013).

FDI outflows in these countries are accompanied by overseas patent registrations, indicating that the three countries, in implementing international economic activities, are very concerned about the PRP system to protect their assets in overseas markets. This also indicates a similarity of FDI flow characteristics from the United States, Japan and Germany that allegedly are dominated by sectors with high technology intensity so that the role of the PRP system in the investment destination country becomes one of the important instruments in the consideration of implementing the FDI. This research consists of (1) Introduction, (2) Literature Review, (3) Method, (4) Result and Discussion, and (5) Conclusion.

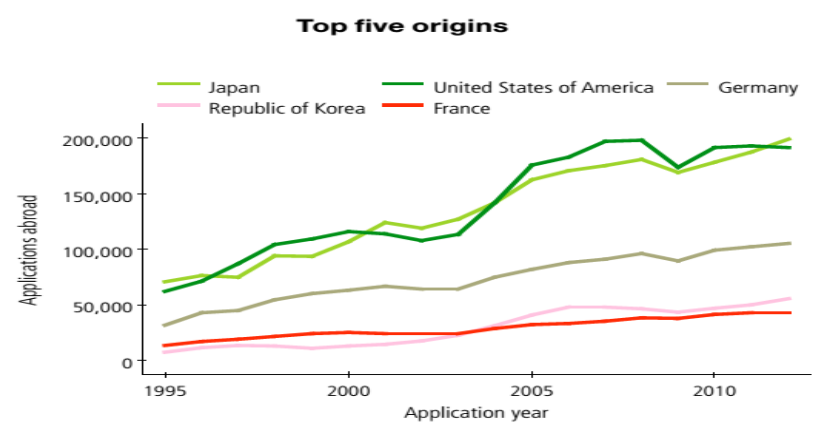

Fig 1. Trends of patent applications filed abroad (5 largest countries) Source : WIPO Indicator, 2013

\section{LITERATURE REVIEW}

The OLI Framework usually identifies international production of foreign firm based on Ownership advantage (O), Localization Advantage (L) and Internalization advantage (I) (Dunning, 1988; Dunning \& Lundan, 2008). The OLI framework only observes the patent protection system instrument in a country as one of the advantages of the MNC decision in implementing international production.

Helpman (1993) described the transmission mechanism of how the patent protection system affects the FDI inflow in a country through the North-South Model terminology. North represents the country in which innovation occurs, while
South is the country that imitates the technology discovered by the North.

Glass \& Saggi, (2002) and Glass (2005) developed a Helpman model by adding the entry mode issue of North firms, when the firms decide to implement FDI or export based on the PRP system level through a profit approach of the respective modes. North is the source (s) and South is the host (h). Firms from the source will choose the FDI mode if the profit gained is greater than conducting export, in perfect condition by applying a strong PRP system without imitations of the host country firms. The profit of source firms will be higher if the firms implement FDI rather than export, because of the low production costs in the south and no additional cost because it is imitated by the host country. This will certainly increase the FDI flow from source firms to the host, and vice versa.

Horstmann and Markusen (1987) argued that the PRP level can affect the company choice to perform licensing or FDI, whereas a strong PRP level will tend to replace FDI with licensing. This is related to the internalization theory, by minimizing transaction costs caused by FDI activities.

A number of empirical studies indicate the relationship between the PRP system and FDI. Ushijima (2013) examined the effects of the PRP system in the host country against the outward FDI of Japanese firms in the period of 1985-2004. Ushijima used a negative binomial regression estimation because the FDI as a dependent variable has a discrete value, which is the number of subsidiaries from Japannese firm that has established over a time interval of 5 years in 58 investment destination countries. Results indicate that the PRP system has a significant positive effect on the FDI outflows of Japanese firms to several countries. However, different outcomes are obtained if FDI outflows from Japanese firms are focused on developing countries where the PRP system has no significant effect.

Wagh (2003) observed the PRP system in 43 countries on FDI from US firms in 1976-1999. Research outcomes indicate that a strong PRP system positively affects FDI inflows. This reflects that the presence of a strong PRP system will provide a familiar climate for U.S. firms businesses, and in addition they will not incur additional costs to prevent theft of technology.

Hsu \& Tiao (2015) analyzed the effects of PRP system in eleven Asian countries on FDI inflows in 1985-2010. By using the GMM estimation, research outcomes indicate that the PRP system in the host country has a significant positive effect. In addition, Hsu \& Tiao (2015) also analyzed countries individually, and found that there is a negative and significant relationship in Malaysia, Indonesia, India and Thailand; while in Singapore, there is no any significant impact between the PRP system and FDI.

Besides increasing FDI, the PRP system can reduce FDI as stated in an empirical study implemented by Yang \& Maskus (2001) which found that royalty revenues on US firms that do not affiliate and the licensing costs increase in countries that have a strong PRP level compared to firms that have affiliates; 
this is due to the PRP system level in the country that does not affect the FDI inflows. The PRP system can encourage more FDI in the host country that has the capacity to imitate the technology of the home country. On the other side, the effects of PRP system on FDI may change negatively if the imitation capacity performs an artificial in line with a very strong PRP system; because licensing is considered more favorable than FDI (Nunnenkamp \& Spatz, 2004). Nicholson (2007) analyzed investment behavior conducted by multinational companies from US. The PRP level is strong in a country where multinational companies tend to implement FDI, if investments need high capital costs (capital intensive). While if the company needs costs for researches and high developments (technology-intensive), then they tend to implement licensing.

\section{METHODS}

\subsection{Model Specification}

Referring to Ushijima (2013), the general model of gravity is used. The variables consist of the size of state income and distance between the two countries; and the addition of variables that would cause friction in international commodities and capital flows (Bergstrand \& Egger, 2011). Since the PRP system can cause friction in the FDI current, the gravity model is used in this study. The general equation is as follows:

$$
\ln \left(F D I_{i j t}\right)=\alpha+\beta P R P_{j t}+\gamma Z_{j t}+\varepsilon_{i t}
$$

In this research, the FDI inflow as the dependent variable is used to observe the effect of PRP system on FDI from the coefficient of parameter $\beta$ as the main variable. The hypothesis built in this research is that a strong PRP system will provide a positive effect on the FDI inflows in developing countries. As the proxy of the measurement of PRP system, an index that was developed by Papageorgiadis, et al. (2014) is applied, with an index scale of $0-10$ (the higher the index value, the more effective the application of the PRP system and vice versa). The index was developed through a transaction cost approach that emerged due to the PRP system in the time period of 1998-2011. Whereas, the three components of index forming are service cost, property right protection cost and monitoring cost. Some study used the index to analyze the relationship of the patent system and innovation (Papageorgiadis \& Sharma, 2016) and economic growth (Alexiou et al., 2016).

Control variables to be used in this research denoted by $Z_{j t}$ are variables that allegedly may affect FDI inflows in the host country, which are $\left(\gamma_{1}\right)$ GDP per capita, $\left(\gamma_{2}\right)$ distance which is measured from the capital of three developed countries to 19 capitals of developing countries as host countries, and $\left(\gamma_{3}\right)$ total population in a country which is expected to have a positive effect.Other control variabels related are $\left(\gamma_{4}\right)$ human capital and market orientation of the host country, and $\left(\gamma_{5}\right)$ which is the institutional and government policy factors related to the international economic activities that have important roles on FDI inflows.

$$
\begin{aligned}
& \ln \left(F D I_{i j t}\right)=\alpha+\boldsymbol{\beta}\left(\boldsymbol{P R} \boldsymbol{P}_{j t}\right)+\gamma_{1} \ln \left(G D P P C_{j t}\right)+ \\
& \left.\gamma_{2} D I S T_{i j}\right)+\gamma_{3} \ln \left(\mathrm{POP}_{j t}\right)+ \\
& \gamma_{4} \text { ECONFREE }_{j t}+\gamma_{5} \text { HUMANCAP }_{j t}+ \\
& \boldsymbol{\varepsilon}_{i t}
\end{aligned}
$$

\subsection{Data Sources}

This research uses secondary data obtained from various sources; the data type is a panel data. The selection of developing countries as the host country is based on the group of economic classification issued by the World Economic Outlook Report 2017 (IMF, 2017). The 19 developing countries in this research are Argentina, Brazil, Chile, Colombia, Venezuela, Mexico, China, India, Indonesia, Jordan, Malaysia, the Philippines, Thailand, Hungary, Poland, Romania, Russia, Turkey, and South Africa; while the 3 home

\begin{tabular}{|c|c|c|c|}
\hline Variables & Definitions & Data Souces & Units \\
\hline$F D I_{i j t}$ & $\begin{array}{l}\text { Value of FDI outflow } \\
\text { from country }(i) \text { to country } \\
(j) \text { in year }(t)\end{array}$ & UNCTAD & USD \\
\hline$P R P_{j t}$ & $\begin{array}{l}\text { The value of the patent } \\
\text { index in country }(j) \text { in year } \\
(t)\end{array}$ & $\begin{array}{l}\text { National patent } \\
\text { systems strength index } \\
\text { scores (Papageorgiadis } \\
\text { et al., 2014) }\end{array}$ & $0-10$ \\
\hline$G D P P C_{j t}$ & $\begin{array}{l}\text { The real value of GDP per } \\
\text { capita in country }(j) \text { in } \\
\text { period } t \text { (constant } 2010)\end{array}$ & World Data Bank & USD \\
\hline$D I S T_{i j}$ & $\begin{array}{l}\text { Distance between capitals } \\
\text { city from country }(i) \text { to } \\
\text { country }(j)(1000 \mathrm{~km})\end{array}$ & $\begin{array}{l}\text { www.timeanddate.com/ } \\
\text { worldclock/distance. }\end{array}$ & $\mathrm{Km}$ \\
\hline$P O P_{j t}$ & $\begin{array}{l}\text { The total population of } \\
\text { country }(j) \text { in year }(t)\end{array}$ & World Data Bank & $\begin{array}{l}\text { Million } \\
\text { Person }\end{array}$ \\
\hline$E C O N F R E E_{j t}$ & $\begin{array}{l}\text { Index of Economic } \\
\text { Freedom of the World in } \\
\text { country }(j) \text { in period }(t) \text {, } \\
\text { represents market } \\
\text { orientation and policies } \\
\text { taken in host country } \\
\text { country }\end{array}$ & $\begin{array}{l}\text { Index Eonomic of } \\
\text { Freedom of The World, } \\
\text { Fraser institute }\end{array}$ & $0-10$ \\
\hline$H U M A N C A P_{j t}$ & $\begin{array}{l}\text { The average number of } \\
\text { years required by residents } \\
\text { aged } 25 \text { years and older to } \\
\text { conduct formal education. }\end{array}$ & $\begin{array}{l}\text { United Nations } \\
\text { Development } \\
\text { Programme (UNDP) }\end{array}$ & year \\
\hline
\end{tabular}
countries in this research are the United States, Japan and Germany. FDI flow data are taken from the United National Conference on Trade and Development (UNCTAD) 20022011.

The real value data of GDP per capita (constant 2010 US\$) and total population are originated from the World Bank (World Bank's Development Indicator), while the distance data between the capital of the home country and host country are obtained from www.timeanddate.com/worldclock/distance, data of Human Capital from the United Nations Development Program (UNDP) and Index Economic Freedom of the World from the Fraser Institute. The main variables in this research are using the index value of the National Patent Systems Strength established by Papageorgiadis et al. (2014).

\section{RESULT AND DISCUSSION}

\subsection{Descriptive Statistics}


Descriptive statistics of the variables used in this study are shown in Table 2 and Figure 2 describing the average growth of a PRP system in developing countries, which overall has a positive trend during 2002-2011.

The initial period from 2000 until 2003 was a transition period, and then in 2003 to 2008 the PRP system in developing countries increased significantly in line with the adjustment of the regulation. Based on data of WIPO members (2017), most of the developing countries amended/improved the preparation of regulations related to the PRP system in the transition period of 2001-2003.

Table 2. Descriptive Statistics

\begin{tabular}{|l|l|l|l|l|}
\hline \multicolumn{1}{|c|}{ Variable } & \multicolumn{1}{c|}{ Mean } & \multicolumn{1}{c|}{ Std.Dev } & \multicolumn{1}{c|}{ Min } & \multicolumn{1}{c|}{ Max } \\
\hline LnFDI & 5.8187 & 1.9065 & 0 & 9.4881 \\
\hline PRP & 4.3877 & 1.1041 & 2.5 & 7.5 \\
\hline LnGDPPC & 8.7266 & 0.6872 & 6.697 & 9.5947 \\
\hline LnPOP & 17.973 & 1.3797 & 15.4126 & 21.019 \\
\hline DIST & 8.6054 & 4.3751 & 0.52 & 18.377 \\
\hline HUMANCAP & 8.4552 & 1.8728 & 4.6 & 12 \\
\hline ECONFREE & 6.6064 & 0.7235 & 3.96 & 8.01 \\
\hline
\end{tabular}

Number of Observations, $\mathrm{N}=570$

\section{Average PRP System Index in 19 Developing Countries}

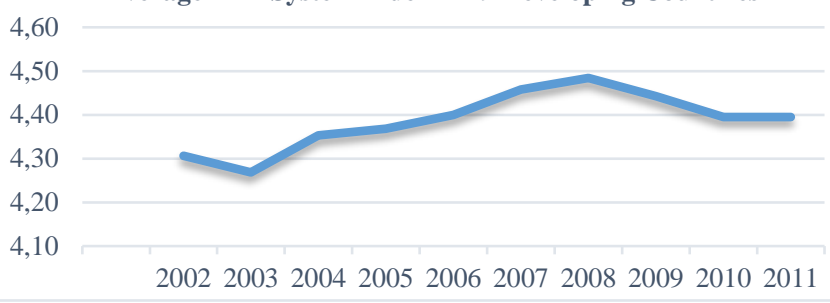

Fig.2. Average trend of the PRP system in developing countries

The period of system upgrading lasted until 2008. The global crisis affected the PRP system in developing countries; make it decline until 2010. The global crisis also affected software piracy because the consumers tend to keep their PC longer, and older devices tend to use unlicensed software (Business Software Alliance, 2009). In 2009-2010 a pattern of piracy software purchases occurred in developing countries because of the increase of software prices. A common method occurring in developing countries is by buying one legal device and installing it in multiple computers. Apart from that, the sales pattern of new PCs is by selling software and PCs separately to reduce the selling price, in order to meet consumers' demands; consequently, this will trigger a higher purchase of pirated software. This can be observed in 2010, wherein the commercial value of software piracy increased by $14 \%$ globally and touched the record total amounting to $\$ 58.8$ billion (Business Software Alliance, 2010, 2011).

\subsection{Empirical Result and Discussion}

Table 5 Estimation outcomes, either FE or RE indicate that the main variable (PRP) positively affects FDI inflows in 19 developing countries; while the control variable of the GDPPC variable does not have significant effect on the FE estimation. Unlike the RE estimation, all control variables significantly affect the FDI inflows. In the RE estimation, all variables indicate a positive relationship except the distance between the home country and the host country that shows a negative relationship; the R-squared value is 0.4166 .

The main variable $(\beta)$ as the aim of this research indicates positive outcomes with a significant level by $5 \%$ whereby every 1 point increase of the PRP system index will increase FDI inflows by $34.7 \%$. This means that countries with an increased index value indicate an increased effectiveness and efficiency in the PRP system, and this will implicate the trust level of the home country as the investor,. An increased strength level of the patent protection system will reduce the risk of the imitation threat, so that the sense of security certainty of the investors will increase the probability of the FDI inflow value. These result are in line with the outcomes of a number of empirical studies implemented (Awokuse \& Yin, 2010b; Hsu \& Tiao, 2015; Seyoum, 2006; Ushijima, 2013; Wagh, 2003), stating that strengthening the PRP system in the host country will increase the probability FDI inflows.

These results also indicate that the enforcement of the TRIPS Agreement for developing countries is effective. With the enactment of the TRIPS Agreement, most of the developing countries seek to strengthen the PRP system by regulation amendments on the PRP system. The implication of reinforcement on the PRP system impact increased the FDI inflows, indicating the importance of the PRP system implementation in international economic activities. The importance of the PRP system is also visible in a number of trade agreements, wherein 141 of the 256 Preferential Trade Agreements (PTA) under WTO regulate the issue on intellectual property (Seuba, 2013). Positive results also indicate that the motives of FDI of home country are for both decreasing production costs, and expanding markets since the size of domestic markets $\mathrm{n}$ developing country are still potential to growing and enlarge (Awokuse \& Yin, 2010b; IMF, 2003).

\begin{tabular}{|c|c|c|}
\hline \multirow[t]{2}{*}{ Dependent Variable } & \multicolumn{2}{|c|}{ LnFDI } \\
\hline & Fixed Effect & Random Effect \\
\hline$P R P$ & $\begin{array}{c}0.5082 * * * \\
(0.1889)\end{array}$ & $\begin{array}{c}0.3467 * * \\
(0.1455)\end{array}$ \\
\hline LnGDPPC & $\begin{array}{c}0.3296 \\
(0.5024)\end{array}$ & $\begin{array}{c}1.2376 * * * \\
(0.2570)\end{array}$ \\
\hline LnPOP & $\begin{array}{l}3.8636^{* * *} \\
(1.8153)\end{array}$ & $\begin{array}{c}1.3374 * * * \\
(0.1438)\end{array}$ \\
\hline DIST & (omitted) & $\begin{array}{c}-0.1103 * * * \\
(0.0395)\end{array}$ \\
\hline HUMANCAP & $\begin{array}{c}0.3286 * * \\
(0.1436)\end{array}$ & $\begin{array}{c}0.2434 * * * \\
(0.0878)\end{array}$ \\
\hline ECONFREE & $\begin{array}{c}0.5319 * * \\
(0.2192)\end{array}$ & $\begin{array}{c}0.4601 * * \\
(0.1869)\end{array}$ \\
\hline Overall $\mathrm{R}^{2}$ & 0.1734 & 0.4166 \\
\hline Observations & 458 & 458 \\
\hline
\end{tabular}

while the numbers in brackets () indicate standard error.

Other variables also indicate significant result: GDP per capita, number of population in the host country, human capital and economic freedom indicate positive relationships. Meanwhile, variable distance also has a significant effect on FDI inflows and indicates a negative relationship. 


\section{CONCLUSIONS}

The Patent Protection System (PRP) has become an important instrument in attracting foreign direct investments (FDI) in line with the adoption and enactment of the Agreement on Trade Related Intellectual Property Rights (TRIPS) for WTO members, because it will protect and reduce the risk of imitating assets owned by foreign investors.This research aims to observe the effect of the PRP system in developing countries against the FDI inflows from innovator countries (United States, Japan, and Germany) to 19 developing countries in 2002-2011. Unlike the previous researches, the measurement of the PRP system in this study uses the index established by Papaeorgiadis (2014); since this index can observe the effectiveness of applying the PRP system in a country through the cost transaction approach. Analysis outcomes indicate that the PRP system in the countries have significant effects and have a positive relationship to FDI inflows, meaning that developing countries with a strong PRP system have higher probabilities to attract foreign direct investments from countries with high innovation levels. In addition, all other control variables such as market size, human capital, government institution, regulation and distance also significantly affect the FDI inflows.

This research has limitations in terms of determining the analysis unit because it is performed at country level. This is conducted because of the limited information related to data of the industrial sector. It would be better to continue the research to the industrial or company level, in order to obtain more specific outcomes; so that it can be observed which industry sector has a higher sensitivity in relation to the PRP system.

\section{REFERENCES}

[1] Alexiou, C., Nellis, J., \& Papageorgiadis, N. (2016). The effect of patent enforcement strength and FDI on economic growth. Multinational Business Review, 24(4), 334-353.

[2] Awokuse, T. O., \& Yin, H. (2010a). Does Stronger Intellectual Property Rights Protection Induce More Bilateral Trade? Evidence from China's Imports. World Development, 38(8), 1094-1104.

[3] Awokuse, T. O., \& Yin, H. (2010b). Intellectual property rights protection and the surge in FDI in China. Journal of Comparative Economics, 38(2), 217-224.

[4] Business Software Alliance. (2009). 08 Piracy Study. Sixth Annual BSA-IDC Global Software.

[5] Business Software Alliance. (2010). 09 Piracy Study. Seven Annual BSA - 09 Piracy Study.

[6] Business Software Alliance. (2011). 2010 Piracy Study. Eighth Annual BSA Global Software.

[7] Dunning, J. H. (1988). The Eclectic Paradigm of International Production: A Restatement and Some Possible Extensions Author ( s ): John H . Dunning Source: Journal of International Business Studies, Vol . 19 , No . 1 ( Spring , 1988 ), pp . 1-31 Published by: Palgrave Macmi. Journal of International Business Studies, 19(1), 1-31.

[8] Dunning, J. H., \& Lundan, S. M. (2008). Multinational Enterprises and the Global Economy, Second Edition. (Second Edi). Edward Elgar Publishing Limited.

[9] Ginarte, J. C., \& Park, W. G. (1997). Determinants of patent rights: A cross-national study. Research Policy, 26(3), 283-301.

[10] Glass, A. J. (2005). Intellectual Property Policy and International Technology Diffusion. Texas.
[11] Glass, A. J., \& Saggi, K. (2002). Intellectual property rights and foreign direct investment. Journal of International Economics, 56, 387-410.

[12] Helpman, E. (1993). Innovation , Imitation , and Intellectual Property Rights. Econometrica, 61(6), 1247-1280.

[13] Horstmann, I., \& Markusen, J. R. . (1987). Licensing versus Direct Investment: A Model of Internalization by the Multinational Enterprise. The Canadian Journal of Economics, 20(3), 464-481.

[14] Hsu, J., \& Tiao, Y.-E. (2015). Patent rights protection and foreign direct investment in Asian countries. Economic Modelling, 44, 1-6.

[15] IMF. (2003). Foreign Direct Investment in Emerging Market Countries. IMF Working Papers.

[16] IMF. (2017). World Economic Outlook: Gaining Momentum? World Economic Outlook April 2017. Washington D.C.

[17] Ivus, O. (2010). Do stronger patent rights raise high-tech exports to the developing world? Journal of International Economics, 81(1), 38-47.

[18] Javorcik, B. S. (2004). The composition of foreign direct investment and protection of intellectual property rights: evidence from transition economies. European Economic Review, 48, 39-62.

[19] Lee, J.-Y., \& Mansfield, E. (1996). Intellectual Property Protection and U.S Foreign Direct Investment. The Review of Economics and Statistics, 78(May), 181-186.

[20] Lesser, W. (2001). The Effect of TRIPS Mandated Intellectual Property Rights on Economic Activities in Developing Countries.

[21] Nabokin, T. (2014). Global Investment Decisions and Patent Protection: Evidence from German Multinationals (Munich Discussion Paper No. 2014-40). Munich

[22] Nicholson, M. W. (2007). The impact of industry characteristics and IPR policy on foreign direct investment. Review of World Economics, 143(1), 27-54.

[23] Nunnenkamp, P., \& Spatz, J. (2004). Intellectual property rights and foreign direct investment: A disaggregated analysis. Review of World Economics/Weltwirtschaftliches Archiv, 393-414.

[24] OECD. (2002). Foreign Direct Investment for Development-Maximising Benefits, Minimising Costs. OECD.

[25] Papageorgiadis, N., \& Sharma, A. (2016). Intellectual property rights and innovation: A panel analysis. Economics Letters, 141, 70-72.

[26] Papageorgiadis, N., Cross, A. R., \& Alexiou, C. (2014). International patent systems strength 1998-2011. Journal of World Business, 49(4), 586-597.

[27] Park, W. G. (2008). International patent protection: 1960-2005. Research Policy, 37(4), 761-766.

[28] Seuba, X. (2013). Intellectual property in preferential trade agreements: What treaties, what content? Journal of World Intellectual Property, 16(5-6), 240-261.

[29] Seyoum, B. (1996). The Impact of Intellectual Property Rights on Foreign Direct Investment. The Columbia Journal of World Business, Spring, 50-59.

[30] Seyoum, B. (2006). Patent Protection and Foreign Direct Investment. Thunderbird International Business Review, 48(5), 389-404.

[31] Smith, P. J. (1999). Are weak patent rights a barrier to U.S. exports? Journal of International Economics, 48(1), 151-177.

[32] Smith, P. J. (2001). How do foreign patent rights affect U.S. exports, affiliate sales, and licenses? Journal of International Economics, 55(2), 411-439.

[33] UNCTAD. (2015). World Investement Report 2015: Reforming International Investment Governance. United Nations Publication. New York and Genveva.

[34] Ushijima, T. (2013). Patent rights protection and Japanese foreign direct investment. Research Policy, 42(3), 738-748.

[35] Wagh, S. (2003). Inward Foreign Direct Investment and Patent Rights : Empirical Evidence From OECD and Non OECD Countries. American University, Washington, D C.

[36] WIPO. (2013). World Intellectual Property Indicators 2013. WIPO Economics and Statistics Series. Geneva.

[37] World Bank. (2002). Global Economic Prospects and the Developing Countries. Washington D.C. 
[38] Yang, G., \& Maskus, K. E. (2001). Intellectual property rights, licensing, and innovation in an endogenous product-cycle model. Journal of International Economics, 53(1), 169-187 